\title{
PENGEMBANGAN MULTIMEDIA INTERAKTIF BERBASIS INTERNET PADA BERITA WACANA LISAN KELAS VII SMP NEGERI 2 TIMANG GAJAH
}

\author{
Suryana ${ }^{1}$, Abdul Hamid, K. ${ }^{2}$ \\ SMP N 2 Timang Gajah, Teknologi Pendidikan Pascasarjana Universitas Negeri Medan \\ inongperpus@gmail.com ${ }^{1}$
}

\begin{abstract}
Abstrak: Penelitian ini bertujuan untuk: (1) menghasilkan multimedia interaktif yang layak digunakan, mudah dipelajari siswa dan dapat dipakai untuk pembelajaran individual, (2) mengetahui keefektifan multimedia interaktif yang dikembangkan pada mata pelajaran berita wacana lisan. Jenis penelitian ini adalah penelitian pengembangan yang menggunakan model pengembangan Borg dan Gall yang dipadu dengan model pengembangan pembelajaran Dick dan Carey. Hasil penelitian menunjukkan; (1) materi mata pelajaran kualifikasi sangat baik; (2) desain pembelajaran kualifikasi sangat baik, (3) rekayasa perangkat lunak dan desain grafis kualifikasi sangat baik. Hasil pengujian hipotesis membuktikan bahwa terdapat perbedaan yang signifikan antara hasil belajar siswa yang dibelajarkan dengan menggunakan multimedia interaktif dengan hasil belajar siswa yang dibelajarkan dengan menggunakan media cetak dan audio. Hal ini ditunjukkan dengan hasil pengolahan data diperoleh $t_{\text {hitung }}=3,328$ pada taraf signifikansi $\alpha=0.05$ dengan $\mathrm{dk} 56$ diperoleh $\mathrm{t}_{\text {tabel }}=1.67$, sehingga $\mathrm{t}_{\text {hitung }}>\mathrm{t}_{\mathrm{tabel}}$, efektifitas penggunaan multimedia interaktif $=80.46 \%$. Disimpulkan bahwa hasil belajar kelompok siswa yang dibelajarkan dengan menggunakan multimedia interaktif sebesar $80,46 \%$ lebih tinggi dari kelompok siswa yang dibelajarkan dengan menggunakan media cetak dan audio sebesar $71.72 \%$.
\end{abstract}

\section{Kata Kunci: pengembangan multimedia interaktif berbasis internet, berita wacana lisan}

\begin{abstract}
This study aimed to: (1) generate a viable interactive multimedia use, easy to learn and can be used for the students' individual learning, (2) determine the effectiveness of interactive multimedia that is developed on the subjects of news of oral discourse. This type of research is the development of research development model Borg and Gall combined with learning development model of Dick and Carey. The results showed; (1) The subject matter is very good qualification; (2) instructional design excellent qualifications, (3) software engineering and graphic design excellent qualifications. Hypothesis testing results prove that there is a significant difference between the learning outcomes of students that learned using interactive multimedia learning outcomes of students that learned to use the print and audio media. This is indicated by the data processing results obtained $\mathrm{t}=3.328$ at significance level $\alpha=0: 05$ to $56 \mathrm{hp}$ obtained table $=1.67$, so thitung $>$ ttable, the effective use of interactive multimedia $=80.46 \%$. It was concluded that the results of the study group of students that learned using interactive multimedia amounted to $80.46 \%$ higher than the group of students that learned to use the print and audio media by $71.72 \%$.
\end{abstract}

Keywords: Internet-based interactive multimedia development, news of oral discourse

\section{PENDAHULUAN}

Melihat perkembangan ilmu dan teknologi, pembelajaran secara umum sedikit banyaknya terpengaruh oleh adanya perkembangan dan penemuan-penemuan dalam bidang keterampilan dan komputerisasi. Pengaruh perkembangan tersebut nampak jelas dalam upaya-upaya pembaharuan sistem pendidikan dan pembelajaran. Oleh karena itu, media pembelajaran menjadi suatu bidang yang seyogianya dikuasai oleh setiap guru profesional.
Tumbuhnya kesadaran terhadap pentingnya pengembangan media pembelajaran di masa yang akan datang, diharapkan akan dapat direalisasikan dalam praktik. Banyak usaha yang dapat dikerjakan, di samping memahami penggunaannya, para gurupun dituntut untuk mengembangkan keterampilan "membuat sendiri" media yang menarik, murah dan efesien, dengan tidak menolak kemungkinan pemanfaatan alat modern yang sesuai dengan kebutuhan ilmu pengetahuan dan teknologi untuk mencapai keberhasilan dalam 
kegiatan pembelajaran di era industrialisasi saat ini.

Untuk mencapai keberhasilan tersebut, guru juga sebaiknya tidak melupakan siswa untuk memanfaatkan semua alat indra yang dimilikinya. Artinya, dapat di lakukan dengan menampilkan rangsangan (stimulus) yang dapat diproses dengan berbagai indera. Semakin banyak alat indera yang digunakan untuk menerima dan mengelola pesan semakin besar kemungkinan pesan tersebut dimengerti dan diharapkan dapat menerima dan menyerap dengan mudah. Baik pesan-pesan dalam materi yang disajikan dalam sebuah media pembelajaran.

Menurut Levie (dalam Arsyad, 2010:9), yang membacakan hasil-hasil penelitian tentang belajar melalui stimulus gambar dan stimulus kata atau visual dan verbal menyimpulkan bahwa stimulus visual membuahkan hasil belajar yang lebih baik untuk tugas-tugas seperti mengingat, mengenali, mengingat kembali, dan menghubung-hubungkan fakta dan konsep. Dilain pihak, stimulus verbal memberi hasil belajar yang lebih apabila pembelajaran itu melibatkan ingatan yang berurut-urutan(sekuensial). Hal ini merupakan salah satu bukti dukungan atas konsep dual coding hypothesis (hipotesis koding ganda).

Hal ini juga sependapat dengan Paivio (dalam Arsyad, 2010:9) yang menyatakan bahwa, "ada dua sistem ingatan manusia, satu untuk mengolah simbol-simbol verbal kemudian menyimpannya dalam bentuk proposisi image, dan yang lainnya untuk mengolah image nonverbal yang kemudian disimpan dalam bentuk proposisi verbal".

Belajar dengan mengunakan indera ganda pandangan dan pendengaran berdasarkan konsep di atas akan memberikan keuntungan bagi siswa dikarenakan Siswa akan lebih termotivasi dalam belajar, dibandingkan materi pelajaran yang hanya disampaikan dengan satu stimulus pandang atau dengar.

Para ahli memiliki pandangan yang searah mengenai hal itu. Perbandingan pemerolehan hasil belajar melalui indera pandang dan indera pedengaran sangat menonjol perbedaannya seperti yang dijelaskan oleh Bough (dalam Arsyad, 2010:10) yaitu, "kurang lebih $90 \%$ hasil belajar seseorang di peroleh melalui indera pandang, dan hanya sekitar 5\% diperoleh melalui indera pendengaran, dan 5\% lagi dengan indera lainnya". Sedangkan menurut Dale (dalam
Arsyad, 2010:10) memperkirakan bahwa, "pemerolehan hasil belajar melalui indera pandang berkisar 75\%, melalui indera dengar sekitar 13\%, dan melalui indera lainya sekitar $12 \% "$.

Tingkat keabstrakan jumlah jenis indera yang turut serta selama penerimaan isi pembelajaran/pesan sangat berperan besar dalam proses pembelajaran. dikarenakan oleh pengalaman langsung akan memberikan kesan paling utuh dan paling bermakna mengenai informasi dan gagasan yang terkandung dalam pengalaman itu, hal ini terjadi karena melibatkan indera penglihatan, pendengaran, penciuman, dan peraba. Ini dikenal dengan learning by doing.

Tingkat keabstrakan pesan akan semakin tinggi ketika pesan itu dituangkan ke dalam lambang-lambang seperti bagan, grafik atau kata. Pesan yang terkandung dalam lambang-lambang, akan ditafsirkan dengan indera yang terbatas, yakni indera penglihatan dan indera pendengaran. Meskipun tingkat partisipasi fisik berkurang, keterlibatan imajinatif semakin bertambah dan berkembang. Sesungguhnya, pengalaman kongkret dan pengalaman abstrak dialami silih berganti; hasil belajar dari pengalaman langsung mengubah dan memperluas jangkauan abstraksi seseorang, dan sebaliknya, kemampuan interpretasi lambang kata membantu seseorang untuk memahami pengalaman yang di dalamnya ia terlibat langsung. Untuk itu dibutuhkan sebuah media yang dapat melibatkan alat indera peserta didik dalam kegiatan pembelajaran.

Media pembelajaran itu sendiri, terdiri atas dua unsur penting, yaitu unsur peralatan atau perangkat keras (hardware) dan unsur pesan yang dibawakannya (softwere). Sehingga media pembelajaran memerlukan peralatan untuk menyajikan pesan, namun yang terpenting bukanlah peralatan itu, tetapi pesan atau informasi belajar yang dibawakan oleh media tersebut, media merupakan salah satu komponen utama dalam pembelajaran selain, tujuan, materi, metode dan evaluasi, maka sudah seharusnya dalam pembelajaran guru menggunakan media pelajaran yang disajikan dengan menggunakan media elektronik yang didesain untuk kepentingan belajar mengajar. Pemilihan media di sini sangatlah penting, karena kedudukan media yang strategis dapat menunjang motivasi dan keberhasilan dalam belajar. Dengan tidak mengindahkan konsep pembelajaran sebagai sebuah sistem yang di 
dalamnya terdapat suatu totalitas yang terdiri atas sejumlah komponen yang saling berkaitan untuk mencapaian tujuan. Untuk itu diperlukan media yang sesuai dengan materi pembelajaran yang akan disampaikan, agar proses pembelajaran ini tepat sasaran dan sesuai dengan kurikulum dan silabus yang ada di sekolah tersebut.

Dilihat dari pengadaan media pembelajaran, Susilana (2009:61) menjelaskan: media dapat dikelompokkan kedalam dua jenis, yaitu media yang sudah tersedia di lingkungan sekolah atau tersedia di pasaran (media by utilization), dalam hal ini media dirancang secara khusus oleh perusahaan tertentu sesuai dengan kurikulum yang berlaku, diproduksi secara masal, dan biasanya harganya relatif murah sehingga guru dengan mudah dapat memiliki dan menggunakannya karena media ini sudah siap pakai. jenis yang kedua disebut (media by design) media yang menuntut guru atau ahli media untuk merancang media sesuai dengan kebutuhan dan tujuan pembelajaran tertentu.

Masing-masing media pasti memiliki kekurangan dan kelebihan. Kelebihan dari media siap pakai adalah hemat dalam waktu, tenaga dan biaya untuk pengadaannya. kekurangannya media siap pakai belum tentu sesuai dengan kebutuhan, tujuan, dan karakteristik materi yang akan diajarkan di sekolah yang dimaksud. Dan untuk media by design kekurangannya dalam merancang media adalah memerlukan waktu, tenaga dan biaya. Adapun kelebihan dari media ini kecil kemungkinan ketidak sesuaian media dengan kebutuhan materi dan tujuan yang diharapkan dalam proses pembelajaran karena yang mendesain adalah guru itu sendiri. Di sini guru juga diharapkan tidak hanya berberan sebagai transformator artinya guru berperan hanya sebagai penyampaian pesan dengan menggunakan komunikasi langsung (direct communication), pola ini membuat siswa kurang aktif karena, siswa hanya menerima materi saja. Seperti halnya analogi gelas yang siap diisi air. Konsep ini tidak sesuai dengan konsep pembelajaran (instructional), pembelajaran memandang siswa sebagai individu yang aktif, memiliki kemampuan dan potensi yang perlu dieksplorasi secara optimal.

Selain memandang penting peranan siswa dalam belajar, proses pembelajaran juga menuntut peran guru lebih luas. Peran tersebut adalah sebagai desainer pembelajaran dalam kata lain mampu merancang sebuah pembelajaran yang baik dan termasuk di dalamnya merancang media pembelajaran. Sebaik-baiknya media yang digunakan dalam pembelajaran adalah memiliki tingkat relevansi dengan tujuan, materi dan karakteristik siswa. Di lihat dari wewenang dan interaksinya dalam pembelajaran, guru adalah orang yang paling menguasai materi, mengetahui tujuan apa yang mesti dibuat dan mengenali betul kebutuhan siswanya. Dengan demikian alangkah baiknya kalau media juga dibuat oleh guru. Karena guru yang mengetahui secara pasti kebutuhan untuk pembelajarannya, termasuk permasalahanpermasalahan yang dihadapi siswa pada materi yang diajarkan. Disinilah peran guru sebagai creator (menciptakan media yang tepat, efesien dan menyenangkan bagi siswa).

Media yang dapat dibuat guru tidak terbatas jenis dan bentuknya, tergantung hasil pemilihannya mana yang paling tepat, dari sekian banyak media yang cocok untuk siswa. Selain itu media yang umum digunakan saat ini adalah media berbasis komputer seperti media presentasi yang kemudian di koneksi dalam bentuk internet. Maka sangat tepat jika guru mampu membuat media minimal media grafis dan media presentasi berbantu komputer dengan berbasiskan internet.

Keberadaan internet yang telah meluas sampai tingkat sekolah menengah saat ini belum banyak digunakan untuk meningkatkan prestasi, khususnya dalam pembelajaran bahasa Indonesia. Penggunaan internet dalam bidang pendidikan hingga saat ini belum maksimal. Pembelajaran berbasis internet merupakan komponen sistem penyampaian pengajaran yang dapat digunakan dalam mendukung proses pembelajaran. Penerapan berbasis internet dilandasi oleh persepsi bahwa pembelajaran akan berlangsung dengan baik, efektif, dan menyenangkan jika didukung oleh media pembelajaran yang dapat menarik minat dan perhatian siswa.

Pembelajaran berbasis internet merupakan sebuah program pembelajaran yang digunakan dalam proses pembelajaran dengan menggunakan perangkat lunak berupa komputer dan internet yang berisi materi pelajaran. Dalam pembelajaran berbasis internet ini, sajian utamanya berupa bacaan dan demonstrasi. Tujuan dari pembelajaran ini adalah untuk memberikan pemahaman secara tuntas kepada siswa mengenai materi atau pelajaran yang sedang dipelajarinya. Dalam pembelajaran ini, 
guru sebagai tutor berorientasi pada upaya membangun motivasi belajar siswa melalui penggunaan software komputer yang berbasis internet.

Belajar dengan bantuan komputer atau belajar dengan bantuan media yang lain, misalnya: buku, kaset, dan sebagainya, memiliki tujuan yang sama yaitu memberi pengetahuan kepada siswa. Akan tetapi untuk saat ini pembelajaran berbasis internet merupakan salah satu solusi yang cukup baik dalam dunia pendidikan terutama dalam proses belajar dan mengajar karena mencakup semua media yang digunakan dalam belajar. Mulai dari materi untuk dibaca, suara yang memberi penjelasan sampai tersedianya soal latihan dan pembahasannya. Selain itu juga memungkinkan pemanajemenan waktu belajar yang lebih efektif dan fleksibel.

Penggunaan internet sebagai media pembelajaran memberikan kemungkinan pengelolaan proses pembelajaran yang lebih inovatif, karena penggunaan internet sebagai multimedia interaktif diharapkan dapat membuat siswa belajar secara mandiri sesuai dengan kecepatan dan daya tangkap masingmasing siswa. Dengan adanya multimedia interaktif di harapkan dapat membantu menambah wawasan guru dalam menyajikan media yang menarik untuk siswa, sehingga tidak membuat jenuh dan bosan dengan media mengajar yang itu-itu saja. Dengan adanya multimedia interaktif ini maka kejenuhan dan kebosanan siswa terhadap materi pelajaran yang diajarkan dengan media cetak (buku), akan berubah menjadi lebih menarik dan menyenangkan.

Hal ini sesuai dengan yang disampaikan oleh Arsyad (2010: 70), "multimedia diartikan sebagai lebih dari satu media. Ia bisa berupa kombinasi antara teks, grafik, animasi, suara, dan vidio. Dan Susilana (2009: 126) juga menjelaskan, "definisi media interaktif ialah alat atau sarana pembelajaran yang berisi materi, metode, batasan-batasan, dan cara mengevaluasi yang dirancang secara sistematis dan menarik untuk mencapai kompetensi/subkompetensi mata pelajaran yang diharapkan sesuai dengan tingkat kompleksitasnya".

Dari penjelasan kedua ahli di atas maka dapat disimpulkan bahwa multimedia interaktif adalah media yang terdiri lebih dari satu unsur media yang di dalamnya terdapat materi, metode, batasan-batasan, dan cara mengevaluasi yang sengaja dirancang secara sistematis dan menarik.

Multimedia interaktif ini diharapkan mampu meningkatkan motivasi dan efektifitas hasil belajar bagi penggunanya. Pembelajaran dengan menggunakan multimedia interaktif juga dapat memberikan respon terhadap stimulus yang diberikan oleh siswa. Selain itu setiap respon dimungkinkan untuk diberikan penguatan (reinforcemen) secara otomatis yang telah terprogram, penguatan terhadap jawaban benar dan salah dari siswa reinforcemen diberikan untuk meningkatkan motivasi dan ketertarikan siswa pada program pembelajaran yang didesain. Hal ini sesuai dengan tori belajar Behaviorisme (Stimulus-Respons) di mana belajar merupakan perubahan tingkah laku yang terjadi berdasarkan paradigma S-R (StimulusRespons), yaitu suatu proses yang memberikan respons tertentu terhadap yang datang dari luar.

Pembelajaran multimedia interaktif juga dapat digunakan oleh siswa secara individual, tidak hanya dalam setting kelas di sekolah, tetapi juga di rumah. Materi dapat diulang-ulang sesuai kehendak siswa karena telah disajikan dalam bentuk CD pembelajaran. Atau dapat pula disajikan secara klasifikasi dengan jumlah siswa maksimal 50 orang di ruang komputer, atau kelas biasa, dan dapat dipandu oleh guru atau cukup mendengarkan uraian narasi dari narator yang telah tersedia di program komputer dengan bantuan proyektor.

Selain itu multimedia interaktif juga dapat menumbuhkan keingintahuan siswa terhadap materi dan merubah rasa ingin tahu untuk mempelajari media itu sendiri. Rancangan isi dan desain multimedia interaktif, memberi peluang untuk menumbuhkan kreatifitas siswa melalui kegiatan-kegiatan belajar dengan menggunakan multimedia interaktif. Selain itu visualisasi dan audiovisual informasi yang disampaikan, akan menumbuhan motivasi belajar terhadap siswa di dalam kelas. Seperti teori belajar Ausubel, materi yang dipelajari diasimilasikan dan dihubungkan dengan pengetahuan yang telah dimiliki sebelumnya. Belajar seharusnya merupakan apa yang disebut asimilasi bermakna. Untuk itu diperlukan dua persyaratan: (1) materi yang secara potensial bermakna, dan dipilih serta diatur oleh guru dan harus sesuai dengan tingkat perkembangan serta pengalaman masa lalu, (2) Suatu situasi belajar yang bermakna. Faktor motivasional memegang peranan penting dalam teori ini. 
Berdasarkan uraian di atas, dapat dipahami bahwa untuk meningkatkan motivasi dan hasil belajar, seorang guru hendaknya mampu untuk memberikan atau menampilkan media belajar yang menarik, sehingga siswa dapat memahami makna dari isi materi mendengarkan berita melalui wacana lisan. Pada materi ini biasanya guru menyajikan materi pelajaran dengan bantuan media yang berbeda-beda yaitu, buku, koran, audio pembacaan berita, sehingga media tersebut tidak dirancang menjadi satu kesatuan yang utuh atau multimedia yang lebih efesien dan inovatif. Dan dari multimedia interaktif tersebut diharapkan agar siswa memiliki kemampuan untuk mengungkapkan atau menunjukkan makna dari isi yang terkandung dalam media pembelajaran yang telah disajikan. Sehingga bentuk visual/audiovisual yang di kemas dalam multimedia interaktif khususnya dalam materi pembelajaran yang disampaikan dalam satu media pembelajaran diharapkan dapat memberikan inovasi dan motivasi yang menunjang keberhasilan dalam tujuan pembelajaran di sekolah.

\section{METODE PENELITIAN}

Metode yang digunakan dalam penelitian ini adalah metode kuasi eksperimen. Sampel penelitian sebanyak 58 siswa yang terdiri dari 29 siswa sebagai kelas eksperimen yang diberi perlakuan menggunakan multimedia interaktif dan 29 siswa sebagai kelas kontrol yang menggunakan media cetak dan audio sebagaimana yang berlangsung selama ini dalam proses pembelajaran.

\section{HASIL DAN PEMBAHASAN \\ Hasil}

Data analisis kebutuhan tersebut ditampilkan pada Tabel 1.

Tabel 1. Data Analisis Kebutuhan

\begin{tabular}{|c|c|c|c|c|c|c|}
\hline \multirow[b]{2}{*}{ No } & \multirow[b]{2}{*}{ Jenis Informasi } & \multirow[b]{2}{*}{ Jawaban } & \multicolumn{3}{|c|}{ Frekuensi } & \multirow[b]{2}{*}{$\begin{array}{l}\text { Persen- } \\
\text { tase }\end{array}$} \\
\hline & & & $\begin{array}{l}\text { Gu } \\
\text { ru }\end{array}$ & Siswa & Jlh & \\
\hline 1. & $\begin{array}{l}\text { Telah Mengenal atau tidak mengenal } \\
\text { multimedia interaktif dengan Macromedia } \\
\text { Flash Professional } 10\end{array}$ & $\begin{array}{l}\text { - Ya } \\
\text { - Tidak }\end{array}$ & $\begin{array}{c}4 \\
36\end{array}$ & $\begin{array}{c}5 \\
53\end{array}$ & $\begin{array}{c}9 \\
89\end{array}$ & $\begin{array}{c}9,00 \% \\
89,00 \%\end{array}$ \\
\hline 2. & $\begin{array}{l}\text { Menggunakan atau tidak menggunakan } \\
\text { multimedia interaktif dalam proses } \\
\text { pembelajaran }\end{array}$ & $\begin{array}{l}\text { - Ya } \\
\text { - Tidak }\end{array}$ & $\begin{array}{c}5 \\
35\end{array}$ & $\begin{array}{c}0 \\
58\end{array}$ & $\begin{array}{c}5 \\
93\end{array}$ & $\begin{array}{c}5,00 \% \\
93,00 \%\end{array}$ \\
\hline 3 & $\begin{array}{llr}\text { Memerlukan atau tidak memerlukan } \\
\text { multimedia } \\
\text { pembelajaran }\end{array}$ & $\begin{array}{l}\text { - Ya } \\
\text { - Tidak }\end{array}$ & $\begin{array}{c}36 \\
3\end{array}$ & $\begin{array}{c}58 \\
0\end{array}$ & $\begin{array}{c}94 \\
3\end{array}$ & $\begin{array}{c}94,00 \% \\
3,00 \%\end{array}$ \\
\hline
\end{tabular}

Berdasarkan hasil angket analisis kebutuhan yang disebarkan oleh guru dan siswa diperoleh kesimpulan sebagai berikut:

1. Sebagian besar guru maupun siswa $(89 \%)$ menyatakan belum mengenal multimedia interaktif dengan Macromedia Flash Professioanal 10 hanya sebagian kecil (9\%) guru dan siswa yang menyatakan telah mengenal media tersebut.

2. Sebagian besar (88\%) guru menyatakan tidak menggunakan multimedia interaktif dengan Macromedia Flash Professioanl 10 dalam proses pembelajaran dan seluruh siswa (100\%) menyatakan tidak pernah menggunakan media tersebut.

3. Sebagian besar guru (91\%) menyatakan memerlukan multimedia interaktif dalam proses pembelajaran dan seluruh siswa $(100 \%)$ menyatakan memerlukannya.

Berdasarkan hasil analisis kebutuhan dapat disimpulkan bahwa pengembangan multimedia interaktif memang sangat dibutuhkan oleh guru dan siswa dalam proses pembelajaran. Hasil wawancara secara lisan kepada guru bidang studi bahasa Indonesia, menyatakan bahwa mereka membutuhkan multimedia interaktif untuk menunjang proses pembelajaran karena mereka mengakui sulit mendapatkan media pembelajaran yang efektif untuk menyampaikan materi berita wacana lisan.

Berikut hasil rangkuman persentase rata-rata hasil penilaian terhadap multimedia interaktif materi berita wacana lisan oleh ahli materi, ahli desain pembelajaran, ahli rekayasa 
perangkat lunak, uji coba perorangan, uji coba dilihat pada tabel 2 berikut ini. kelompok kecil dan uji coba lapangan dapat

Tabel 2. Rangkuman Persentase Rata-Rata Hasil Penilaian Terhadap Multimedia Interaktif Berbasi Internet Pada Materi Berita Wacana Lisan

\begin{tabular}{|l|l|c|c|}
\hline No & \multicolumn{1}{|c|}{ Responden } & $\begin{array}{c}\text { Persentase } \\
\text { Rata-rata }\end{array}$ & Kriteria \\
\hline 1 & Ahli materi & $93,83 \%$ & Sangat Baik \\
\hline 2 & Ahli desain pembelajaran & $88,55 \%$ & Sangat Baik \\
\hline 3 & Ahli rekayasa perangkat lunak & $94,10 \%$ & Sangat Baik \\
\hline 4 & Siswa pada uji coba perorangan & $91,43 \%$ & Sangat Baik \\
\hline 5 & Siswa pada uji coba kelompok kecil & $93,63 \%$ & Sangat Baik \\
\hline 6 & Siswa pada uji coba lapangan & $97,96 \%$ & Sangat Baik \\
\hline & Rata-Rata & $\mathbf{9 3 , 2 5 \%}$ & Sangat Baik \\
\hline
\end{tabular}

Beberapa kegunaan dan manfaat dalam penggunaan multimedia interaktif berbasis internet pada materi berita wacana lisan sebagai berikut: (1) materi mudah dipahami karena konsep yang disajikan direncanakan untuk mempermudah siswa dan sistematis, (2) multimedia interaktif berbasis intertaktif memberi kesempatan siswa untuk belajar sesuai dengan kecepatan masing-masing individu, (3) belajar lebih cepat dan menarik sehingga tidak menimbulkan kebosanan karena dilengkapi dengan gambar-gambar dan animasi serta soal latihan yang bervariasi. (4) adanya kesempatan dalam menjawab soal pada waktu tes jika jawaban dianggap salah dengan tujuan agar siswa dapat memahami materi yang telah dipelajari, (5) multimedia interaktif ini juga dapat digunakan sebagai alternatif media pembelajaran secara konvensional maupun individual.

\section{Pembahasan}

Dari hasil pengolahan data penelitian yang dilakukan, terdapat perbedaan hasil belajar materi berita wacana lisan antara siswa yang dibelajarkan dengan menggunakan multimedia interaktif dan siswa yang dibelajarkan dengan tanpa menggunakan multimedia interaktif yaitu rata-rata hasil belajar berita wacana lisan siswa yang dibelajarkan dengan menggunakan multimedia interaktif lebih tinggi dibandingkan dengan siswa yang dibelajarkan tanpa menggunakan multimedia interaktif. Hal ini dapat dilihat dari hasil nilai rata-rata berita wacana lisan siswa yang yang diajar dengan multimedia interaktif yaitu sebesar 12,06 (80,46 $\%)$, sedangkan hasil nilai rata-rata berita wacana lisan siswa yang diajar tanpa multimedia interaktif sebesar 10,76 (71,72\%).
Dari data ini membuktikan bahwa penggunaan multimedia interaktif lebih baik dalam meningkatkan komptensi dan pengetahuan siswa pada materi berita wacana lisan dari pada tanpa menggunakan multimedia interaktif. Hal ini sesuai dengan pendapat pakar dan hasil penelitian yang relevan sebagai berikut.

Keunggulan penggunaan komputer dalam pembelajaran adalah seperti yang diungkapkan oleh Phillip (1997: 27) yaitu :

If interactive multimedia not suited to transmission of information, which is better handled by book and lectures, then guestion is raised, what is interactive multimedia good for? (1) Material is hard to visualize, such as microscopic processes, (2) Material which is three dimensional, which can't easily be conveyed whit traditional two dimensional media such book and whiteboard, (3) Dynamic processes, where it important to understand the relation of moving object, (4) Material which has abroad context, where a number of ideas need to be linked to form an understanding of the whole, not just the part, (5) Simulation of expensive, dangerous or complex pracesses, where undesrstanding may be hindered by mechanical detail of performing the process, or where there is no possibility of using the real equipment.

Hasil penelitian tentang Model Pembelajaran Interaktif dengan Animasi Simulasi berbantuan komputer dalam upaya Remidi Miskonsepsi Orbital Atom dan molekul yang dilakukan oleh Sri Mursiti, dkk menyimpulkan bahwa model pembelajaran yang interaktif melalui CD pembelajaran dapat meningkatkan prestasi yang ditunjukkan dengan adanya perbedaan skor yang signifikan antara sebelum dan sesudah penerapan model 
pembelajaran animasi simulasi berbantuan komputer mengenai orbital atom dan molekul di Jurusan Kimia FMIPA UNNES.

Penggunaan multimedia interaktif memungkinkan siswa untuk lebih mudah memahami berita wacana lisan karena dari media pembelajaran ini memungkinkan siswa untuk berinteraksi langsung, memiliki gambargambar, animasi, sound background dan soal yang hasilnya dapat dikirim langsung melalui email guru, sehingga setiap siswa tidak kesulitan lagi dalam membayangkan dalam hal membaca gambar karena didalam media ini telah dijelaskan secara detail. Selain itu, media pembalajaran ini sangat praktis, karena media ini dapat dibawa oleh siswa dan dapat dipelajari dirumah karena multimedia interaktif tersebut dalam bentuk flash. Media pembelajaran ini juga dapat menguji kemampuan dan pemahaman siswa secara langsung melalui tes atau soal-soal latihan pilihan berganda yang memiliki durasi waktu dan kunci jawaban yang benar, sehingga mahasiswa dapat mengetahui kesalahan yang telah dilakukan dalam mengerjakan soal latihan tersebut. Multimedia interaktif juga dilengkapi dengan rangkuman yang dapat membantu siswa memperoleh ringkasan materi kuliah yang dipaparkan.

Pembelajaran dengan multimedia interaktif berbasis internet juga memungkinkan para guru bidang studi bebas melakukan interaksi dengan siswa sehingga pembelajaran tersebut bersifat interaktif yang membuat pembelajaran terfokus pada informasi yang sedang dipelajari. Hal ini berbeda dengan pembelajaran tanpa menggunakan multimedia interaktif, siswa tidak berinteraksi langsung pada sumber informasi dan pembelajaran didominasi oleh guru yang menyajikan informasi secara linier atau satu arah, selain itu dalam materi berita wacana lisan sangat dituntut siswa untuk mampu membuat kesimpulan dari berita dengan menggunakan $5 \mathrm{~W}+1 \mathrm{H}$, membuat contoh berita dan menganalisis berita. Hal tersebut tentunya akan cukup menyulitkan dan membuat kegiatan belajar mengajar menjadi kurang menarik. Tanpa multimedia interaktif berbasis internet siswa mendapatkan sumber informasi hanya dari guru yang bersangkutan dengan materi-materi yang ada pada buku. Pembelajaran tanpa menggunakan multimedia interaktif menempatkan guru menggunakan kontrol pembelajaran dengan aktif, sementara siswa relatif pasif menerima dan mengikuti apa yang disampaikan guru. Guru menyampaikan materi secara terstruktur dengan harapan materi berita wacana lisan yang disampaikan dapat dikuasai dengan baik dengan terfokus kepada kemampuan akademik.

Walaupun dalam penelitian diperoleh data bahwa hasil belajar materi berita wacana lisan siswa lebih tinggi jika dibelajarkan dengan menggunakan multimedia interaktif dari pada hasil belajar berita wacana lisan siswa yang dibelajarkan tanpa menggunakan multimedia interaktif, namun dalam pelaksanaannya kedua media pembelajaran ini telah mampu meningkatkan pemahaman dan hasil belajar berita wacana lisan siswa. Keefektifan penggunaan multimedia interaktif adalah sebesar 80,46\% dan tanpa media sebesar 71,72 $\%$.

\section{PENUTUP}

Berdasarkan rumusan, tujuan, hasil dan pembahasan penelitian pengembangan multimedia interaktif berbasis internet yang dikemukakan sebelumnya maka dapat disimpulkan sebagai berikut:

1) Hasil validasi dari ahli materi terhadap multimedia interaktif berbasis internet pada berita wacana lisan yang dikembangkan menunjukkan bahwa; (1) kualitas materi pembelajaran dinilai sangat baik dengan persentase rata-rata sebesar $95,00 \%$, (2) kualitas strategi pembelajaran dinilai sangat baik dengan persentase rata-rata sebesar $94,00 \%$, (3) kualitas sistem penyampaian pembelajaran dinilai sangat baik dengan persentase rata-rata sebesar 92,50\%. Dengan demikian multimedia interaktif berbasis internet pada materi berita wacana lisan yang dikembangkan dengan menggunakan beberapa program dan Macromedia Flash Professioanl 10 secara keseluruhan termasuk dalam kategori "Sangat Baik".

2) Hasil validasi dari ahli desain pembelajaran terhadap multimedia interaktif berbasis internet pada berita wacana lisan yang dikembangkan dengan menggunakan beberapa program dan Macromedia Flash Professional 10 menunjukkan bahwa; (1) kualitas desain pembelajaran dinilai sangat baik dengan persentase rata-rata $87,50 \%$, (2) kualitas desain informasi dinilai sangat baik dengan persentase rata-rata sebesar $87,50 \%$, (3) kualitas desain interaksi dinilai baik dengan Persentase rata-rata sebesar 92,50\%, (4) kualitas desain presentasi dinilai sangat baik dengan persentase rata-rata sebesar 
$81,70 \%$. Berdasarkan hasil validasi tersebut disimpulkan bahwa multimedia interaktif berbasis internet pada berita wacana lisan yang dikembangkan termasuk dalam kriteria sangat baik sehingga dapat diterima dan layak digunakan dalam proses pembelajaran.

3) Hasil validasi dari ahli rekayasa perangkat lunak terhadap multimedia interaktif berbasis internet pada berita wacana lisan yang dikembangkan dengan beberapa program dan Macromedia Flash Professioanal 10 dinyatakan bahwa; (1) pemrograman dinilai sangat baik dengan persentase rata-rata sebesar $93,33 \%$, (2) kualitas teknis/tampilan dinilai sangat baik dengan persentase rata-rata sebesar $92,70 \%$. Dengan demikian multimedia interaktif yang dikembangkan secara keseluruhan termasuk dalam kriteria sangat baik.

4) Menurut tanggapan siswa/i kelas VII SMP N 2 Timang Gajah pada uji coba perorangan dinyatakan bahwa multimedia interaktif yang dikembangkan dengan beberapa program dan Macromedia Flash Professional 10 termasuk kategori sangat baik dimana aspek materi pembelajaran dinilai dengan persentase rata-rata sebesar $93,39 \%$ dan kualitas teknis tampilan sebesar $89,52 \%$.

5) Menurut tanggapan siswa/i kelas VII SMP N 2 Timang Gajah pada uji coba kelompok kecil dinyatakan bahwa multimedia interaktif yang dikembangkan dengan beberapa program dan Macromedia Flash Professional 10 termasuk kategori sangat baik dimana aspek materi pembelajaran dinilai dengan persentase rata-rata sebesar 91,39\% dan kualitas teknis tampilan sebesar $95,87 \%$.

6) Menurut tanggapan siswa/i kelas VII SMP N 2 Timang Gajah pada uji coba lapangan dinyatakan bahwa multimedia interaktif yang dikembangkan dengan beberapa program dan Macromedia Flash Professional 10 termasuk kategori sangat baik dimana aspek materi pembelajaran dinilai dengan persentase rata-rata sebesar $97,84 \%$ dan kualitas teknis tampilan sebesar 98,08\%.

7) Media pembelajaran yang dikembangkan peneliti layak untuk digunakan sebagai multimedia interaktif pada berita wacana lisan siswa/i kelas VII SMP N 2 Timang Gajah semester ganjil, karena memiliki nilai rata-rata yang lebih tinggi dari nilai median skala Likert.
8) Terhadap penggunaan multimedia interaktif pada tes hasil belajar siswa menunjukkan bahwa hasil belajar siswa yang dibelajarkan dengan menggunakan multimedia interaktif berbasis internet (kelas eksperimen) lebih tinggi $=12,06$ dari hasil belajar siswa yang dibelajarkan dengan menggunakan media pembelajaran buku teks (kelas kontrol) = 10,76. Dengan demikian disimpulkan bahwa terdapat perbedaan yang signifikan antara hasil belajar siswa yang dibelajarkan dengan menggunakan multimedia interaktif dengan hasil belajar siswa yang dibelajarkan dengan media cetak dan audio, dimana diperoleh $t_{\text {hitung }}$ sebesar 3,285 sedangkan $t_{\text {tabel }}$ pada $\alpha=$ 0,05 dengan derajat kebebasan 94 adalah: 1,70 .

Multimedia interaktif memiliki keefektifan sebesar 80,46\% lebih tinggi dari keefektifan media cetak dan audio sebesar $71,72 \%$.

\section{DAFTAR PUSTAKA}

Achmad \& Alek. 2011. Bahasa Indonesia untuk Perguruan Tinggi. Jakarta: Kencana

Arends, Richard I. 2008. Learning To Teach. Yogyakarta: Pustaka Pelajar

Arikunto, Suharsimi. 2006. Prosedur Penelitian Suatu Pendekatan Praktik. Jakarta : Rineka Cipta

Arsyad, Azhar. 2010. Media Pengajaran. Jakarta : Raja Grafindo Persada

Borg, W. \&V Gall, M.D. 1983. Educational Research. An Introduction ( $\left.4^{\text {nd }} \mathrm{ed}\right) . \mathrm{New}$ York \& London: Longman

Chaer, Abdul. 2006. Tata Bahasa Praktis Bahasa Indonesia. Jakarta: Rineka Cipta

Chaer, Abdul. 2009. Sintasis Bahasa Indonesia. Jakarta: Rineka Cipta

Depdiknas. 2005. Kamus Besar Bahasa Indonesia. Jakarta: Balai Pustaka

Dick, W. dan Carey, L. 2005. The Systematic Design of Instruction. United States of America: Scott Foresman and company

Keraf, gorys. 1994. komposisi. Jakarta: Nusa Indah

Hakim, lukmanul. 2004. Cara Ampuh Menguasai Macromedia Flash Profesional 8.0. Jakarta: PT Elex Media komputindo

Jacobsen, David A \& Eggen, Paul. Kauchak, Donald. 2009. Methods for Teaching. Yogyakarta: Pustaka Pelajar 
Juanda \& Rosdyanto. 2007. Intisari Bahasa dan Sastra Indonesia. Bandung: CV Pustaka Setia

Keraf, Gorys. 1991. Tata Bahasa Rujukan Bahasa Indonesia. Jakarta: Grasindo

Reynolds, David \& Muijs, Daniel. 2008. Effevtive Teaching. Yogyakarta: Pustaka Pelajar

Russell, James D \& Smaldino, Sharon. Lowther, Deborah L. 2011. Instructional Technology \& Media For Learning. Jakarta: Kencana

Rusman. 2011. Model-Model Pembelajaran. Jakarta: Rajawali Pers

Sabri, Ahmad. 2010. Strategi Belajar Mengajar Micro Teaching. Ciputat: PT. Ciputat Press

Sapari, Nia Kurniati. 2008. Kopetensi Berbahasa Indonesia untuk Kelas VII SMP/MTS. Jakarta: Pusat Perbukuan Departemen Pendidikan Nasional

Semi, Atar. 1990. Menulis Efektif. Padang: Angkasa Raya

Siregar, Eveline \& Nara, Hartini. 2010. Teori Belajar dan Pembelajaran. Bogor: Ghalia Indonesia

Slameto. 2010. Belajar dan Faktor-Faktor yang Mempengaruhinya. Jakarta : Rhineka Cipta

Sudjana, Nana. 2009. Penilaian Hasil Proses Belajar Mengajar. Bandung : Rosdakarya

Sudjana, Nana. 2005. Metoda Statistika. Bandung: Tarsito

Sugiyono. 2010. Metode Penelitian Kuantitatif, Kualitatif dan $R \& D$. Bandung: Alfabeta

Susilana, Rudi \& Riyana, Cepi. 2009. Media Pembelajaran. Bandung: CV.Wacana Prima

Tarigan, Guntur. 1990. Membaca Sebagai Suatu Keteranipilan Berbahasa. Bandung: Angkasa

Trianto. 2011. Mendesain Model Pembelajaran Inovatif-Progresif. Jakarta: Kencana

Mayer, E. Richard. 2009. Multimedia Learning. Yogyakarta: Pustaka Pelajar

Miarso, Yusufhadi. 2009. Menyemai Benih Teknologi Pendidikan. Jakarta: Kencana 